Deliberationes tudományos folyóirat

14. évfolyam 1. szám 2021/1, 48-58.

Kézirat beérkezése: 2021.04.16.

Kézirat befogadása: 2021.08.16.

DOI: 10.54230/Delib.2021.1.48
Deliberationes Scientific Journal

Vol.14; Ed.No.1/2021, pages: 48-58

Paper submitted: 16th April 2021

Paper accepted: 16th August 2021

DOI: $10.54230 /$ Delib.2021.1.48

\title{
TANTERVI VÁLTOZÁSOK BÉKÉS VÁRMEGYE KÖZÉPFOKÚ ISKOLÁIBAN, AZ 1920-30-AS ÉVEKBEN
}

Lipcsei Imre

Gál Ferenc Egyetem, Pedagógiai Kar

\begin{abstract}
Absztrakt
Magyarországon, mint mindenhol a világon, a közoktatást nagymértékben befolyásolták az oktatáspolitikai változások. A tanulmány a Trianoni békeszerződést követő húsz év neveléstörténeti törekvéseit teszi vizsgálatának tárgyává egy régió, Békés vármegye oktatásügyi helyzetének feltárásával, fókuszálva a középiskolákra vonatkozó tantervi módosításokra.

A téma feldolgozásánál a leíró jelleg mellett elméleti-elemző módszert alkalmazva, helyenként az összehasonlító metodika segítségével nem csak az intézetek egymással való összevetése, de olykor országos kitekintés is megjelenik.

A pedagógusok már az 1920-as években felismerték, hogy a gyermekek közötti tanulási különbözőség nem csak az eltérő képességeik miatt alakult ki, lemaradásuk hátterében többek között szociális hatások is szerepet játszottak. Ezért a meglévő társadalmi és szociális nehézségek miatt örömmel fogadták a Tanterv és Utasításban megengedett tanítói szabadságot, melyek a napjainkban is oly fontos differenciálás lehetöségét villantották fel.

Megismerve a módszertani útmutatásokat, a tantervi vitákat, a haladást segítő kritikai polémiákat kijelenthető, hogy a vármegyei oktatásügy számos olyan értékkel rendelkezik, melyekre bátran lehet támaszkodni napjaink iskolaügyében is.
\end{abstract}

Kulcsszavak: Tantervi változások, oktatáspolitikai, tanulási különbözőség, differenciálás 


\title{
CURRICULAR CHANGES IN SECONDARY EDUCATION OF BÉKÉS COUNTY \\ IN THE 1920S AND 1930S
}

\author{
Imre Lipcsei \\ Faculty of Pedagogy, Gál Ferenc University
}

\begin{abstract}
In Hungary, as everywhere in the world, public education has been greatly influenced by changes in education policy. The study examines the aspirations of contemporary education policies in the twenty years following the Treaty of Trianon by exploring the secondary education of a region, namely Békés County, focussing on curricular modifications in secondary schools.

In addition to descriptive sections, a theoretical-analytical method is also applied to discuss the topic. With the help of the comparative methodology, not only local schools are compared to one another, but a nationwide outlook appears to some extent, too.

As early as the 1920s, educators realized that differences in learning outcomes among children evolved not only due to their different abilities, but social impacts also played a role, inter alia, in their lagging behind. Therefore, owing to the existing social difficulties, they welcomed the teaching freedom allowed by the Curriculum and Instructions, as it pointed to the possibility of differentiation that is so important even nowadays.

Based on the overview of the methodological guidelines, the debates over the curriculum and the critical controversies promoting progress, it can be stated that the county's education has many values that can be firmly relied on in today's educational matters as well.
\end{abstract}

Keywords: Curricular changes, education policy, differences in learning, differentiation 


\section{A BÉKÉS VÁRMEGYEI KÖZÉPISKOLAI KÉPZÉS MEGJELENÉSE ÉS ELTERJEDÉSE}

Békés vármegyében a középfokú oktatás iránt a lakosság részéről a XVIII. század második felében egyre növekvő igény jelentkezett, azonban az első gimnázium csak a XIX. század elején nyílt meg. Élö probléma volt, hogy azok a fiatalok, akik tanulni akartak messze vidékre kerültek iskolába és zömük a tudás birtokában már nem tért vissza Békés vármegyébe, hanem vagy ott maradt, ahol tanult, vagy onnan is továbbállt. A szülők ezért nehéz szívvel engedték el gyermekeiket, de a vármegyének is problémát jelentett a tudással felvértezett fiatalok visszacsábítása. Az agrártermelésre épülő, a fő közlekedésvonalak kiépítésével, a Tiszavölgy (Körösök, Berettyó, Maros) szabályozásával meggyorsított fejlődés nyomán kibontakozó polgárosodás igényeire az evangélikus egyház válaszolt elsőként. Az 1802-ben Szarvason megtartott Békésbánáti Esperesség közgyűlésén elhatározták egy latin iskola felállítását, melynek székhelyéül Mezőberényt választották. Itt azonban nem tudott gyökeret verni a középfokú oktatás mivel a nyomasztó anyagi terhekre nem tudtak megnyugtató megoldást találni. A gimnázium megmentése érdekében 1834-ben a szarvasi nagybirtokosság felajánlását elfogadva az egyház Szarvasra költöztette az intézményt. A Tessedik-féle iskolaépületben működő intézmény felszerelése folyamatosan gazdagodott, müködésének feltétele évről-évre javult. Vajda Péter, majd Benka Gyula igazgatósága alatt a térség jelentős gimnáziumává vált.

Az 1860-70-es években a vármegyében két új gimnázium nyitotta meg kapuit. Békésen a reformátusok, Békéscsabán úffent az evangélikusok próbálkoztak középfokú intézmény felállításával. A gazdasági nehézségek miatt az iskolák státusza többször változott, de a század végére mindkettő elnyerte a főgimnáziumi rangot. Békéscsabán 1900-ban, míg Békésen 1902-ben tartották meg az első érettségi vizsgát.

A gyulai középiskola létesítésének alapját Wenckheim Krisztina grófnő vetette meg azzal, hogy 1892-ben 50.000 forint alapítványt tett katolikus gimnázium létesítésére. A kamataival gyarapodó vagyont az egyház és más mecénások növelték, így 1903-ban összegyült annyi pénz, hogy Gyula város polgármestere és a tanügyi kormány megbízottja aláírta a fögimnázium alapszerződését, melyet két hónap múlva az akkori vallás és közoktatásügyi miniszter, Wlassics Gyula is jóváhagyott. Ebben az évben a tanintézet megkezdte működését. Egyelőre a római katolikus egyházközség bérházában e célra berendezett helyiségeiben, majd 1905-ben átköltözött az újonnan átadott ma is álló épületébe, amit államsegéllyel Gyula városa emeltetett. Az első érettségi vizsgát az 1910-11-es tanév végén tartották.

A lányok számára a Békéscsabai Nőképző Társulat 1874-ben polgári leányiskolát nyitott, melyet több földbirtokos saját költségén müködtetett. 1901-ben az állam lett a fenntartó és már ekkor gimnáziummá kívánták tenni az intézményt. Erre azonban csak 1921-ben nyílott lehetőség. Ebben az évben, amikor az intézmény felvette Lórántffy Zsuzsannának a nevét elrendelték az iskola leánygimnáziummá való fokozatos átszervezését. 
Szeghalmon a gyulaihoz hasonlóan szintén egy magán kezdeményezés hatására indult el a gimnáziumi oktatás. Péter András földbirtokos 1907-ben 1506 kat. hold földet hagyományozott egy Szeghalmon létesítendő középiskola céljaira. A nehéz időkre tekintettel az egyetemes konvent, a tiszántúli egyházkerület javaslatára csak 1926-ban nyitotta meg a reálgimnáziumot. Az alapító okirat szerint a gimnázium úgy bővült, hogy minden évben egy új osztállyal egészült ki, ami természetesen magával vonta a tantestület folyamatos növelését is. A reálgimnázium fejlődése 1933-ban fejeződött be a nyolcadik osztály megnyitásával. E tanév végén tartották meg az első érettségi vizsgát 34 tanulóval.

A vizsgált időszak végén Orosházán nyitott az evangélikus egyház egy újabb gimnáziumot. A községben egy középiskola létesítésére való igény már az 1850-es években jelentkezett, hosszabb-rövidebb ideig működtek magángimnáziumok, de ezek soha nem nyertek hivatalos elismertséget. A sorozatosan sikertelen kísérletek után csak 1933-ban nyílt meg egy gimnázium előkészítő tanfolyam, melynek tanulói a Mezőtúri Református Gimnáziumban tették le évvégén az érettségi vizsgát. 1937-ben határozta el az egyházközség képviselőtestülete, hogy gimnáziumot alapít és azt az I-II osztálylyal megnyitja. A kultuszminiszter megadta az engedélyt az oktatás megindítására, az évenkénti osztálybővítésre és az intézmény 1944-ben megkapta a nyilvánossági jogot.

\section{TANTERVEK VÁLTOZÁSAI A VÁRMEGYE KÖZÉPFOKÚ ISKOLÁIBAN AZ 1920-30-AS ÉVEKBEN}

A vizsgált időszakban a középiskolák akaratukon kívül jelentős változásokon mentek keresztül. Az 1920-as évek elején a békési, a szarvasi, a békéscsabai Rudolf és a gyulai intézmények fögimnáziumként müködtek. Az egyedüli leány középiskola a vármegyében a M. Kir. Áll. Lórántffy Zsuzsanna Leánygimnázium volt, mely 1921től kapta meg a gimnáziumi státuszt.

A fögimnáziumokban kisebb módosításokat leszámítva gyakorlatilag az 1899-i középiskolai tanterv volt érvényben, míg a „Lórántffyban” az 1918-ban kiadott leánygimnáziumok általános óraterve szerint folyt az oktatás. 1924-ben azonban Klebelsberg Kunó által kiadott XI. törvénycikk három középiskola-típust kodifikált: a gimnáziumot, a reálgimnáziumot és a reáliskolát. Mindhárom iskolatípus általánosan képző középiskola volt, melyek irányultsága kissé elágazott. A törvény szerint a középiskola feladata volt, „hogy a tanulót vallásos alapon erkölcsös polgárrá nevelje, hazafias szellemben általános műveltséghez juttassa és a felsőbb tanulmányokhoz szükséges szellemi munkára képessé tegye. A közös nemzeti jellegű tantárgyakon kívül a gimnázium e feladatot a minden irányú humanisztikus, elsősorban latin és görög nyelvi és irodalmi tanulmányokkal, a reálgimnázium föleg a latin és a modern nyelvi és irodalmi tanulmányok segítségével, a reáliskola különösen a modern nyelvek és irodalmak, úgyszintén a mennyiségtani és természettudományi tárgyak tüzetesebb tanításával oldja meg" (Törvénycikk a középiskoláról, 1924). Klebelsberg a Nemzeti Újság 1924. augusztus 23-24-i számában intézkedésének pozitívumai között 
kiemelte, hogy mind a három iskolafajta egyformán képesít minden felsőoktatási tanulmányra és nagy jelentőséget tulajdonított annak, hogy kitolhatóvá vált a gyerekek számára a pályaválasztás. Ez annak volt köszönhető, hogy a nyolc éves tanulmányi idő alatt biztosított volt a különböző iskolatípusokból az átmenet és az igazi választásra csak az érettségi után került sor.

Az új oktatási rend az 1924-25-ös tanévvel vette kezdetét. A VKM törekvése arra irányult, hogy rövid időn belül elterjessze a törvény által újonnan létrehozott iskolatípust, a reálgimnáziumot. Klebelsberg a törvényjavaslat beterjesztésekor kijelentette, hogy „számításom szerint a 106 középiskolából mintegy 20 meg fog maradni humanisztikus gimnáziumnak, 71 átalakul reálgimnáziummá és 15 lesz a reáliskolák száma. Méltóztatnak tehát látni, a reálgimnázium lesz a magyar középiskoláknak túlnyomó része, körülbelül kétharmada" (Glatz, 1990).

A békés vármegyei gimnáziumok közül egyedül a Szarvasi Evangélikus Főgimnázium tartotta meg humanisztikus jellegét, a többi intézmény az 1924-25-ös tanévtől reálgimnáziumként müködött tovább. Természetesen nemcsak az intézmény elnevezése változott meg, hanem bevezették az új tantervet is. Az első évben csak az I. és az V. osztályokban, majd évente felmenő rendszerrel beindítva az 1927-28-as tanévre minden osztályban ennek megfelelően folyt a tanítás. 
1. számú táblázat

A gimnáziumok és a reálgimnáziumok heti óraterve az 1924-es tantervben

\begin{tabular}{|c|c|c|c|c|c|c|c|c|c|c|c|c|c|c|c|c|}
\hline & \multicolumn{2}{|c|}{ I. } & \multicolumn{2}{|c|}{ II. } & \multicolumn{2}{|c|}{ III. } & \multicolumn{2}{|c|}{ IV. } & \multicolumn{2}{|c|}{$\mathrm{V}}$. & \multicolumn{2}{|c|}{ VI. } & \multicolumn{2}{|c|}{ VII. } & \multicolumn{2}{|c|}{ VIII. } \\
\hline & G. & R. & G. & R. & G. & R. & G. & $\mathrm{R}$. & G. & $\mathrm{R}$. & G. & $\mathrm{R}$. & G. & $\mathrm{R}$. & G. & $\mathrm{R}$. \\
\hline Hittan & 2 & 2 & 2 & 2 & 2 & 2 & 2 & 2 & 2 & 2 & 2 & 2 & 2 & 2 & 2 & 2 \\
\hline Magyar & 5 & 5 & 4 & 4 & 3 & 3 & 3 & 3 & 3 & 3 & 3 & 3 & 3 & 3 & 3 & 3 \\
\hline Latin & 6 & 6 & 6 & 6 & 6 & 6 & 6 & 6 & 6 & 5 & 6 & 4 & 5 & 4 & 5 & 4 \\
\hline Német & & & 3 & 3 & 3 & 4 & 3 & 4 & 3 & 3 & 3 & 3 & 2 & 2 & 2 & 2 \\
\hline Görög & & & & & 4 & & 4 & & 4 & & 4 & & 4 & & 3 & \\
\hline Francia vagy & & & & & & & & & & & & & & & & \\
\hline Angol, vagy & & & & & & & & & & & & 5 & & 4 & & 4 \\
\hline Olasz & & & & & & & & & & & & & & & & \\
\hline Történelem & & & & & 3 & 3 & 2 & 2 & 3 & 3 & 3 & 3 & 3 & 3 & 3 & 3 \\
\hline Földrajz & 3 & 3 & 3 & 3 & 2 & 2 & & 1 & & & & 1 & 2 & 2 & & \\
\hline Természet & 2 & 2 & 2 & 2 & & & 3 & 2 & 3 & 3 & 3 & 3 & & & & \\
\hline Kémia & & & & & & & & 2 & & & & & & & & \\
\hline Fizika & & & & & & 2 & & & & & & & 4 & 4 & 4 & 4 \\
\hline Mennyiség & & & & & & & & & & & & & & & & 3 \\
\hline Filozófia & & & & & & & & & & & & & & & 3 & 2 \\
\hline Rajz & & & & & & & & & & & & & & & & 1 \\
\hline Testgyak. & 2 & 2 & 2 & 2 & 2 & 2 & 2 & 2 & 2 & 2 & 2 & 2 & 2 & 2 & 2 & 2 \\
\hline $\begin{array}{c}\text { osztályon- } \\
\text { ként }\end{array}$ & & & 28 & ó. & 30 & & & & & ó. & & & & & & \\
\hline
\end{tabular}

Forrás: Tanterv a középiskolák számára. Budapest, 1924.

A vármegyében működő két középiskolai típus tanterveinek összevetéséből kitűnik, hogy alig van különbség. Az idegen nyelvek esetében a humán gimnáziumban megmaradt a görög, a reálgimnáziumban ezzel szemben a felső négy osztályban három élő idegen nyelvből lehetett választani. A Rudolf Reálgimnáziumban az angolt, míg a másik kettő reálgimnáziumban a francia nyelvet kínálták a tanulóknak.

A másik különbség a reál tárgyaknál jelentkezett. A gimnáziumban nem volt kémia. Igaz a reálgimnáziumban is csak a IV. osztályban jelent meg heti kettő óraszámban. Kettő órával volt több fizikából is, mely többlet a harmadik osztályban jelentkezett. A rajz tantárgy a gimnázium felső tagozatán már nem tartozott a rendes tárgyak 
sorába, ezzel szemben a reálgimnáziumban egy-egy órában hetenként a felsőben is foglalkoztak a tanulók rajzzal. A heti óraterhelés mind a két intézménynél megegyezett, az első két évben 28-28 óra, míg a többi hat évfolyamban 30-30 órát foglalkoztak a diákok a rendes tantárgyakkal. Ezenkívül a délutáni órákban lehetőség nyílott rendkívüli tárgyak felvételére is. Ezeket (többek között a gyorsírás, festés-rajzolás, hegedülés, ének, céllövő tanfolyam) szintén osztályzattal minősítették, de felvételüket külön tandíj megfizetéséhez kötötték.

Természetesen a szaktanárok nem mindegyike tudott azonosulni a központi követelményekkel. Főként azok a pedagógusok álltak elő reformtervekkel, kiknek tantárgyaik alacsony óraszámmal jelentek meg a tantervekben. Véleményüket nem csak a testületen belül artikulálták, hanem különböző sajtóorgánumokban is publikálták. Így tett Kilczner Gyula békéscsabai tanár is, aki a Protestáns Tanügyi Szemlében $A$ fizika helye a reálgimnázium tantervében címü írásában a természettudományok és ezen belül a fizika erőteljesebb súlyozását kéri számon. Az 1926-os természettudományi kongresszus téziseit kölcsönözve kijelentette, hogy „Ma a természettudomány művelése világjelszó a kultúrnemzetek közművelési politikájában” (Kilcner,1930). Ennek megfelelően a természettudományokat a nemzeti életre kiható fontosságuk miatt nagyobb óraszámban képzelte el. Mivel a fizika több tantárgyhoz is kapcsolódik nézetei szerint, ezért mind az alsó és felsőfokon szükségesnek tartotta tanítását. Az érvényben lévő tanterv szerint a fizika a harmadik osztályban csak kettő órával részesült, majd csak a VII-VIII. osztályokban jelenik meg újra, akkor azonban már 4-4 órával. Ezzel szemben Kilczner kifejti, hogy „a fizikai oktatás célját, módszerét, a többi tárgygyal való kapcsolatát, a tanítás ökonómiáját tekintetbe véve, azt hiszem ideálisnak nevezhetnénk azt a tantervet, amely a reálgimnáziumban a fizika tanítására heti 3-3 órát juttatna a III. és IV. osztályban és heti 4-4 órát a VI. VII. VIII-ban, vagyis összesen 17 órát" (Kilczner,1930).

Ugyanebben a számban Nagy Miklós szeghalmi tanár kiemelve a természettudományok fontosságát másra helyezi a hangsúlyt. „Vigyük fel a földrajzot, de csak a leíró földrajzot, a felső osztályokba is és ennek kapcsán domborítsuk ki Magyarország világpolitikai helyzetét. Vonjuk össze a matematika anyagát és óraszámát, tegyük ugyanezt a fizikával, de hozzuk be helyükre a kémiát mai tudományos és gyakorlati fontosságának megfelelő mértékben. Illesszük be az egészségtant a természetrajz tanításának keretébe s adjuk a természetrajztanár kezébe" (Nagy, 1930).

E két tanulmányból is kitűnik, hogy a középiskolai tanárok szakuktól, érdeklődésüktől és talán érdekeiktől függően másként látták a gimnázium és a reálgimnázium feladatait, lehetőségeit. A változtatás igénye nemcsak egyénileg jelentkezett. A különböző felekezetek is kissé eltérő módon látták helyesnek az oktatás irányát. A reformátusok esetében például az „Egyetemes Konvent 148-1932. sz. határozatában megbízta az Országos Református Tanáregyesületet, hogy az új református középiskolai tantervre vonatkozó munkálatát sürgősen készítse el és terjessze az egyetemes tanügyi bizottság elé; elnökségét pedig felkéri, tegye meg illetékes helyen a lépéseket 
aziránt, hogy az 1883. évi XXX. tc. $47 . \S$ b) pontjának hatályon kívül helyezésével államsegélyes református középiskoláink is követhessék a református tantervet az idézett törvénycikk 8.\$-a szerint" (Bessenyei,1932).

A felszólításnak eleget téve a Tanáregyesület hozzákezdett a tanterv kidolgozásához, azonban az 1920-as évek legvégén a minisztérium is tervbe vette a reálgimnáziumi tanterv módosítását. „Ilyen körülmények közt várakozó álláspontra kényszerültünk, mivel új református középiskolai tantervet csak akkor érdemes és célszerü készíteni, ha már az állami tanterv bizonyos mértékü, legalábbis a fontos hatásokat magában foglaló megállapodottságra tesz szert. A reálgimnáziumot valóban reformálták is. De mi mégsem fogtunk újból munkához, mivel ismételten új és új reformhírek szállongtak a levegőben és így vártuk, hogy egyszer csak mégis lelohad a folyton változtatni kész lázas akarat, amely után biztos keretekhez alkalmazkodhatunk"(Be ssenyei,1932).

Bessenyei Lajos szavai jól jellemzik a középiskolai tantervek körüli problémákat, melyek a leányintézetek esetében is hasonló módon jelentkeztek. Békéscsabán a leányiskola 1921-ben vette fel a magyar történelem nagyasszonyának, Lórántffy Zsuzsannának a nevét és még ebben az évben elrendelték az iskola leánygimnáziummá való fokozatos átszervezését. Az 1924/25-ös tanévben már minden osztály gimnáziumi irányú volt. Az oktatás az 1918-ban kiadott és a 377/924. számú rendelettel módosított tanterv szerint folyt, azonban a leány középiskolák számára az 1926. évi XXIV. törvény változást hozott. Két típust kodifikáltak: a leánygimnáziumot és a leánylíceumot. A vallásos, erkölcsös és nemzeti szellemben folyó oktató-nevelő munka mellett meghatározta a törvény, hogy „a közös nemzeti tárgyakon kívül e feladatot a leánygimnázium elsősorban a latin és modern nyelvi és irodalmi tanulmányok segítségével, a leánylíceum elsősorban a modern nyelvek és irodalmak tüzetesebb tanításával oldja meg" (törvénycikk a leányközépiskoláról,1926).

Az 1927. évi 37.313/V. számú rendelettel leánylíceummá alakítják át az első osztályt azzal az igénnyel, hogy felmenő rendszerrel az egész iskola fejlődjön ilyen iskolatípussá.

A fokozatosan átalakuló reálgimnáziumokhoz hasonlóan ebben az intézetben is kétféle iskola működött, a leánygimnázium (a még bennlévő osztályok), valamint a leánylíceum (az újonnan induló osztályokkal). A két tanterv között nem volt nagy különbség. A líceumban a latin helyett az angol, a francia és az olasz közül lehetett választani második élő idegen nyelvként. Békéscsabán a III. osztálytól az angol nyelv került a tantárgyak sorába, de rendkívüli tárgyként VI. osztálytól a francia nyelvet is felvehették a tanulók. Újítás volt, hogy a felső tagozaton rendes tárgyként megjelent a művészettörténet, valamint az ének az V-VI. osztályban is rendes tárgyként szerepelt. Különböző tantárgyak esetében minimális különbség jelentkezett az óraszámok között, azonban a heti terhelés megegyezett mind a két iskolatípusnál.

Az iskola igazgatója az 1926-27-es értesítő végén tudatta a szülőkkel a változást, azonban tájékoztatta őket a leánylíceum státuszáról is. Megnyugtatott mindenkit, hogy a leánylíceum teljes jogú középiskola, amely érettségi bizonyítványt ad és az 
egyetemek minden - a nők számára megnyitott - fakultására felvételre jogosít éppúgy, mint a leánygimnázium. Erre a hirdetményre azért volt szükség, mert a leánygyermekes szülők, nem ismerve az új intézményt, fontolgatták gyermekük beíratását. A következő tanévben az elsősök száma azonban nem hozott jelentős visszaesést, ami jelzi, hogy végül elfogadták a módosítást.

A politika az 1930-as években újra megváltoztatta a középfokú oktatás struktúráját. Alig épült ki a Klebelsberg-féle középiskolai rendszer, az évtized elején a VKM élére került Hóman Bálint beterjesztette az 1934. évi 11. törvényét. Ebben megszüntette a háromféle fiú, és kétféle leány középiskolát és helyettük létrehozta az „egységes középiskolát, a gimnáziumot"(törvénycikk a középiskoláról,1934). Ennek megfelelően az összes békés vármegyei középiskolában az új tanterv szerint indult meg az oktatás. A tantervvel kapcsolatos Utasítások az 109.646/1938. IX. számú rendeletben jelentek meg. Ebben deklarálták, hogy az általános műveltségnek főeleme és egyben a vallásosságon felépülő középiskolai nevelésnek gerince a nemzetismeret. A tanítás középpontjában is a legtágabb értelemben vett nemzeti tárgyak állnak. Ilyen nemzeti tárgyak elsősorban a magyar nyelv, az irodalom és müvészet, a történelem, az állami, gazdasági, társadalmi élet jelenségeinek ismerete, a föld- és néprajz s - bizonyos mértékig - a magyar művelődés történetében alapvető szerepet betöltő latin nyelv. A miniszter rendeletében kifejtette, hogy nemcsak a tananyag megválasztásában, hanem a tanítás módszereiben is meg kell nyilvánulnia a nemzetnevelésnek, melyet össze kellett kapcsolni az egyéni jellemneveléssel.

A fiú és a leánygimnázium tanterve között alig volt különbség. Az első hat osztályban a heti óraterhelés azonos, 31-31 óra volt. A VII-VIII. osztályban azonban a fiúknál plusz egy óra többlet jelentkezik. Eltérés még, hogy a lányoknál a német nyelv oktatása elkezdődött az első osztálytól és a latin csak a harmadiktól, míg a fiúknál ez fordítva volt. A lányoknál az alsó négy osztályban helyet kapott heti kettő óra kézimunka, ehelyett a fiúknál minden évfolyamon heti egy órával többet fordítottak a testnevelésre.

Az újabb tantervi változás ismét felborította az egységes rendet az intézményekben. A gyulai, a békési és a békéscsabai Rudolf gimnáziumban ekkorra már minden osztály reálgimnáziumi tanterv szerint tanult, sőt a szeghalmi gimnáziumban a változás évében adták ki az első reálgimnáziumi érettségit. Az 1935-36-os tanévtől kezdődően azonban újra két tanterv szerint folyt az oktatás. Az újonnan induló osztályok már az egységes gimnáziumi tantervnek megfelelően kezdték el tanulmányaikat, míg a többiek a „régi” követelmények szerint fejezték be az iskolát.

A Lórántffy Zsuzsanna Leánygimnáziumban a jelzett évben három iskolatípus müködött. Az első osztály természetesen az új tanterv szerint indult. A második osztályban az 1934. XI. törvénycikk előkészítésének idején a 1934-35-ös tanévben rendeleti úton Klebelsberg-féle leánygimnáziummá alakították az induló osztályt, abból a célból, hogy átmenetet képezzen a törvény végrehajtási utasításának megjelenésével életbe lépő egységes gimnáziumhoz. Így az adott évben a második osztályban leánygimnáziumi 
tanterv szerint tanítottak, míg a III-VIII. osztályban az 1927. évi 1889. számú rendelet által meghatározott leánylíceumi keretek között tanultak a diákok.

\section{ÖSSZEGZÉS}

A Békés vármegyei gimnáziumok az 1920-30-as években is a VKM rendeleteinek megfelelően alakították át tevékenységüket, a tantervi változásokat felmenő rendszerrel mindegyik intézményben bevezették. ami föleg a Lórántffy leánygimnáziumban okozott diffúz állapotokat.

A vármegyei gimnáziumok a Szegedi Királyi Tankerületi Főigazgatóság alá tartoztak. A Főigazgatóság által delegált tanfelügyelő minden évben tematikus látogatást tartott, mely során a feltételrendszerröl, a müködésröl és az oktató-nevelö munkáról készített átfogó jelentést. Ezen pozitív visszajelzések alapján megállapítható, hogy a Békés vármegyei intézetek megfelelően illeszkedtek a kor gimnáziumi struktúrájába.

Kapcsolattartó szerző:

Lipcsei Imre

Gál Ferenc Egyetem

Pedagógiai Kar

5540 Szarvas

Szabadság u. 4.

lipcsei.imre@gfe.hu
Corresponding author: Imre Lipcsei Faculty of Pedagogy Gál Ferenc University Szabadság str. 4. 5540

Szarvas, Hungary lipcsei.imre@gfe.hu 


\section{IRODALOMJEGYZÉK}

Glatz, F. (Ed.). (1990). Tudomány, kultúra, politika Gróf Klebelsberg Kunó válogatott beszédei és írásai (1917-1932). Európa Könyvkiadó.

Kilczner, Gy. (1930). A fizika helye a reálgimnáziumok tantervében. Protestáns Tanügyi Szemle, (4)5, 162-166.

Nagy, M. (1930). Új református középiskola tanterv. Protestáns Tanügyi Szemle (4)5, 161-162.

Bessenyei, L. (1932). Új református középiskolai tanterv. Protestáns Tanügyi Szemle. (6)8, 223-226.

Bessenyei, L. (1932). Új református középiskolai tanterv. Protestáns Tanügyi Szemle. (6) 8, 223-226.

Országos Törvénytár, M. Kir. Belügyminisztérium. XI. törvénycikk $\$ .1$ (1924). https:// net.jogtar.hu/getpdf?docid $=92400011$.TV\&targetdate $=\&$ printTitle $=1924 .+\% \mathrm{C} 3 \% \mathrm{~A}$ 9vi+XI.+t\%C3\%B6rv\%C3\%A9nycikk\&referer $=1000 \mathrm{ev}$

Országos Törvénytár, M. Kir. Belügyminisztérium. XXIV. törvénycikk \$.1 (1926). https://net.jogtar.hu/getpdf?docid=92600024.TV\&targetdate $=\&$ print Title=1926.+ \%C3\%A9vi+XXIV.+t\%C3\%B6rv\%C3\%A9nycikk\&referer=1000ev

Országos Törvénytár, M. Kir. Belügyminisztérium. XI. törvénycikk \$.4 (1934). https://net.jogtar.hu/ezer-ev-torveny?docid=93400011.TV\&searchUrl=/ezer-evtorvenyei\%3Fpagenum\%3D41 